\title{
BRASH syndrome: More than just syncope
}

\author{
Divya Vangipuram MD, Kenneth Nugent MD
}

\begin{abstract}
The pentad of bradycardia, renal failure, atrioventricular nodal blockade, shock, and hyperkalemia describes the BRASH syndrome, a newly recognized phenomenon in which accumulation of potassium and renally excreted atrioventricular nodal blockers cause a cycle of bradycardia, hypoperfusion, and worsening renal function. Here, we describe a case of $B R A S H$ in an elderly woman whose medications had recently changed, and who presented with bradycardia, anuria, and hypotension. Resolution of symptoms occurred over hours after the correct treatment was started. Furthermore, we review case reports written in recent years for common BRASH syndrome patient characteristics.
\end{abstract}

Keywords: Bradycardia, hyperkalemia, shock, AV nodal blocker, critical care

\section{INTRODUCTION}

BRASH syndrome-bradycardia, renal failure, atrioventricular (AV) nodal blockade, shock, and hyperkalemia-is a newly described clinical disorder first detailed in $2012^{1}$ and recognized in $2016 .^{2}$ It is most often seen in the emergency medicine and critical care settings in elderly patients with cardiac conditions managed with AV nodal blocking agents, underlying kidney disease, and a cause for hypoperfusion. A cycle of worsening kidney function, hyperkalemia, medication accumulation, and bradycardia develops quickly and can progress to multi-organ dysfunction if untreated. ${ }^{2}$

\section{CASE PRESENTATION}

A 75-year-old Caucasian woman with hypertension, hyperlipidemia, type II diabetes mellitus, history of first-degree AV block, and coronary artery disease with two stents placed in 2012 had a witnessed syncopal event while sitting in the lobby of a doctor's office.

Corresponding author: Divya Vangipuram Contact Information: D.vangipuram@ttuhsc.edu DOI: 10.12746/swrccc.v9i40.827
After 10-15 seconds, the patient regained consciousness, was alert and fully oriented, and did not have bowel or bladder incontinence. Paramedics found the patient to have a blood pressure of $70 / 50 \mathrm{mmHg}$ and a heart rate of 28 beats per minute (BPM). She was given atropine and glucagon in route to the hospital.

In the emergency department, vital signs showed blood pressure of $68 / 43 \mathrm{mmHg}$, heart rate of $28 \mathrm{BPM}$, normal body temperature, and oxygen saturation above $92 \%$ on room air. She was placed on a nonrebreather mask for mild tachypnea. She reported 2-3 days of decreased fluid intake, a mild, dull, intermittent left anterior chest pain without radiation and one day of dizziness. Physical examination revealed a groggy but oriented, frail appearing elderly woman with dry oral mucosa, no trauma to the head, clear lung fields bilaterally with mild tachypnea, regularly irregular heart rate without murmur, soft and non-tender abdomen, thready pulses, and cool extremities.

Home medications included subcutaneous insulin, metformin, glimepiride, atorvastatin, aspirin, amitriptyline, amlodipine, furosemide, diltiazem, and metoprolol tartrate. Diltiazem was increased from $240 \mathrm{mg}$ daily to twice a day and metoprolol was decreased from $50 \mathrm{mg}$ twice a day to daily by her cardiologist one week prior to presentation. These doses were changed due to persistent hypertension and borderline bradycardia 
with a heart rate of 56 BPM and a blood pressure of $162 / 63 \mathrm{mmHg}$ at the time of this appointment. She reported strict compliance with all prescribed medications.

\section{INVESTIGATIONS}

Work-up in the emergency department showed a normal complete blood count. Metabolic panel was significant for potassium of $6.4 \mathrm{mmol} / \mathrm{L}$ without hemolysis, bicarbonate of $14 \mathrm{mmol} / \mathrm{L}$, anion gap of 21 , BUN of $35 \mathrm{mg} / \mathrm{dL}$, creatinine of $1.9 \mathrm{mg} / \mathrm{dL}$, eGFR $25 \mathrm{~mL} / \mathrm{min}$, and glucose of $471 \mathrm{mg} / \mathrm{dL}$. Serum acetone was negative. Troponin and one-hour repeat level were within normal range. Serum osmolality was high, and lactate was $7.1 \mathrm{mmol} / \mathrm{L}$. Arterial blood gas showed $\mathrm{pH} 7.136$, pCO2 $29.6 \mathrm{mmHg}$, pO2 $119.4 \mathrm{mmHg}$, bicarbonate $9.8 \mathrm{mEq} / \mathrm{L}$, and lactate $4.72 \mathrm{mmol} / \mathrm{L}$, indicating lactic and metabolic acidosis with acute respiratory compensation. Urinalysis showed no infection and mild glucosuria, proteinuria, and ketonuria. Urine electrolytes showed a fractional excretion of sodium of $0.4 \%$, indicating pre-renal azotemia.

The initial electrocardiogram (ECG, Figure 1) showed sinus arrest with ventricular escape rhythm with rate of 28 beats per minute, QRS 129 milliseconds (ms), QTc $381 \mathrm{~ms}$, peaked T waves, and no P waves. Chest $\mathrm{x}$-ray did not show infiltrates, effusion, or cardiomegaly.

\section{DifFERENTIAL DIAGNOSIS}

As the presentation of BRASH syndrome can vary, the differential diagnosis must be broad. In this case, the differential included hyperkalemia, AV nodal blocker toxicity, infection, hypothyroidism, and cardiac structural, perfusion-related, and conduction abnormalities.

\section{TREATMENT}

For initial resuscitation, the patient was given two doses of $0.5 \mathrm{mg}$ intravenous atropine, $1 \mathrm{mg}$ glucagon, one liter of normal saline, and calcium gluconate and insulin for bradycardia, hypotension, and hyperkalemia respectively. Dextrose was not administered due to hyperglycemia. The patient was started on a dopamine infusion. Over the next 15 minutes, hypotension and bradycardia persisted and the patient began to have altered mentation and increasing drowsiness. Epinephrine infusion was started, and within minutes mentation, blood pressure, and heart rate improved. Dopamine was quickly weaned off after epinephrine was started. The patient remained on the epinephrine infusion for 4 hours.

Due to hyperkalemia, acute kidney injury, and oliguria with $15 \mathrm{~mL}$ of urine output over 3 hours spent in the emergency department, nephrology was consulted, central venous access for emergent dialysis was obtained, and hemodialysis was initiated within an hour. However, due to catheter malfunction secondary to clot formation, dialysis was stopped in 17 minutes. Repeat renal function panel was drawn and showed improvement, with potassium at $5.3 \mathrm{mmol} / \mathrm{L}$, creatinine $1.4 \mathrm{mg} / \mathrm{dL}$, and an eGFR of $36 \mathrm{~mL} / \mathrm{min}$. The patient was given one dose of $10 \mathrm{mg}$ sodium zirconium cyclosilicate (an oral potassium binder) and observed. Over the next 12 hours, she had $500 \mathrm{~mL}$ of urine output.

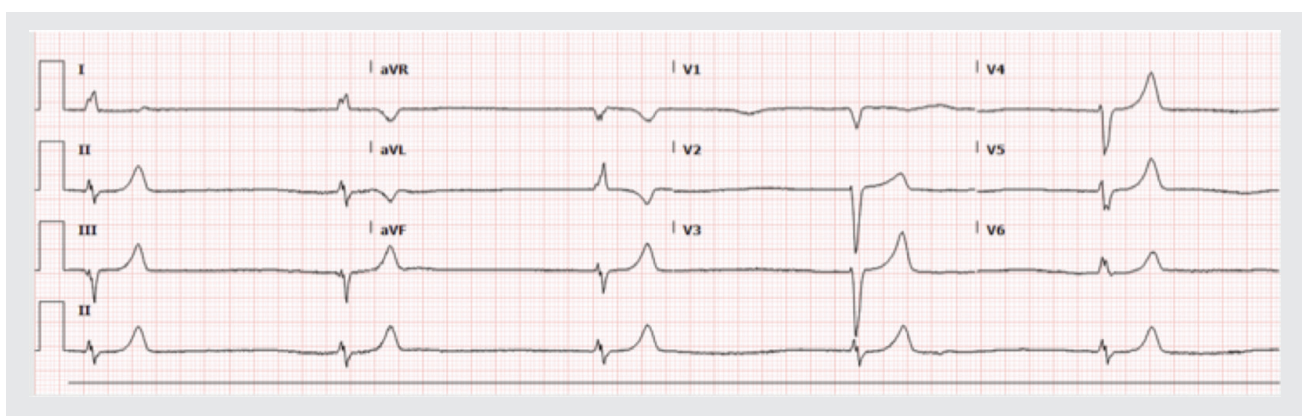

Figure 1. ECG on initial evaluation, which shows junctional rhythm. 


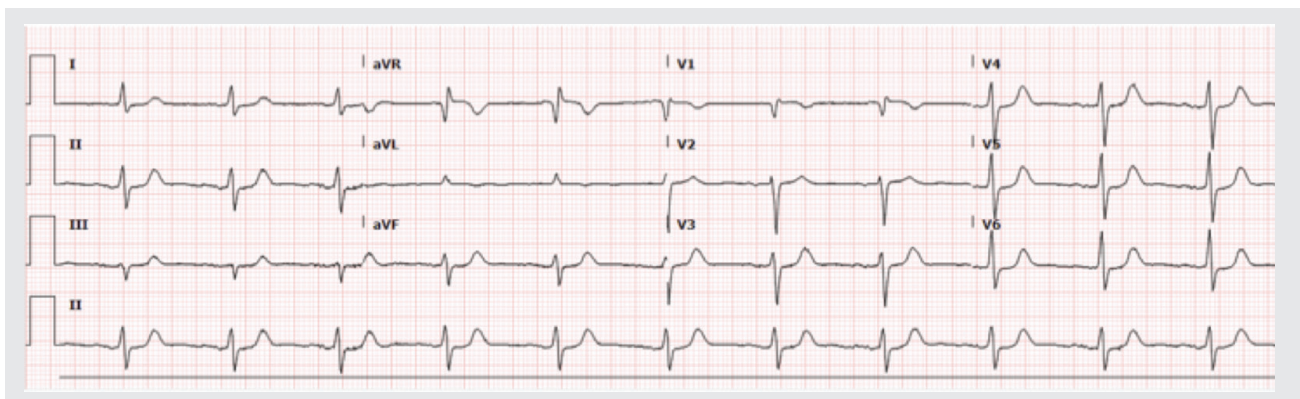

Figure 2. ECG on day of discharge, which shows first degree AV block.

\section{OUTCOME AND FOLLOW UP}

She remained in the hospital for three days, and her overall course was uncomplicated. She spent one night in the intensive care unit as epinephrine was weaned off and was sent to the general ward the next morning. Kidney function continued to improve over the next day. She did not receive dialysis again. Stress test, echocardiogram, and carotid ultrasound were performed and did not reveal mechanical or perfusion defects. An electrocardiogram on the day of discharge showed sinus rhythm with first-degree AV block and left axis deviation (Figure 2), unchanged from prior admissions. On discharge, cardiac medications were revised. Diltiazem and amlodipine were discontinued, $20 \mathrm{mg}$ daily lisinopril was added, and metoprolol tartrate was changed from $50 \mathrm{mg}$ daily to $25 \mathrm{mg}$ BID. She was discharged home on the third day of admission with close follow up with her cardiologist, her primary care physician, and a nephrologist.

At her follow up appointment with the cardiologist, metoprolol was increased to $25 \mathrm{mg}$ in the morning and $50 \mathrm{mg}$ at night. Two weeks later, at her follow up with the primary care physician, she denied new episodes of syncope and a log of heart rate and blood pressure since discharge showed normal, stable vital signs. She was formally diagnosed with CKD III with a baseline creatinine of $1.2 \mathrm{mg} / \mathrm{dL}$ at her follow up with nephrology.

\section{Discussion}

Both beta-blockers and non-dihydropyridine calcium channel blockers (diltiazem, verapamil) are atrioventricular node blocking drugs and are primarily excreted by the kidneys. The crux of BRASH syndrome lies in the synergistic effect of accumulated levels of medication and potassium in the setting of renal dysfunction due to hypoperfusion. This effect causes bradycardia, which reduces cardiac output, and thus decreases renal perfusion, further worsening kidney injury, and causing a vicious cycle. ${ }^{2-4}$

Work-up should initially be directed toward differentiating between hyperkalemia, AV nodal blocker toxicity, and BRASH syndrome with a thorough clinical history. Patients with bradycardia related to hyperkalemia caused by kidney failure, medications, Addison's disease, diabetes, and hemolytic conditions often have potassium levels above $7 \mathrm{mmol} / \mathrm{L}$ and ECG changes, such as peaked $T$ waves and QRS prolongation. Patients with AV nodal blocker toxicity may or may not have hyperkalemia, may report recent changes in cardiac medications, and present in the setting of overdose. BRASH syndrome patients always have hyperkalemia, although levels are often lower than expected given the degree of bradycardia present, and report compliance with medications..$^{2-4}$

Treatment of hyperkalemia, bradycardia, and hypotension should occur concurrently. Hyperkalemia should be addressed immediately, regardless of the degree, and treatment should consist of intravenous calcium to stabilize cardiac myocytes, with insulin, dextrose, and albuterol. ${ }^{2-5}$ Definitive treatment of hyperkalemia, acidosis, and kidney injury after initial stabilization is dictated by urine output-if low or none, dialysis should be pursued quickly. If the patient has urine output, alkalization with bicarbonate infusion and kaliuresis with potassium-wasting diuretics with isotonic fluid replacement and potassium binding agents are the preferred therapy. ${ }^{2-4}$ Bradycardia should be 
Table 1. BRASH Case Series and Reports

\begin{tabular}{|c|c|c|c|c|c|c|c|}
\hline Year & Author & Age & Medications & Chief Complaint & HR & $\mathbf{K}+$ & Treatment \\
\hline $\begin{array}{l}1986- \\
2019\end{array}$ & Farkas $^{2}$ & $\begin{array}{l}70 \text { (mean, } \\
\mathrm{n}=18)\end{array}$ & $\begin{array}{l}\text { AV nodal blockers, } \\
\text { most commonly } \\
\text { verapamil }\end{array}$ & Varied & 45 & 6.8 & Varied \\
\hline $\begin{array}{l}2017- \\
2018\end{array}$ & Ravioli $^{5}$ & $\begin{array}{l}80 \text { (mean, } \\
\mathrm{n}=8 \text { ) }\end{array}$ & Beta blocker & Varied & - & 5.8 & $\begin{array}{l}\text { Fluids, potassium shifting } \\
\text { agents, catecholamine } \\
\text { infusion }\end{array}$ \\
\hline 2019 & Sohal $^{6}$ & 89 & Diltiazem & $\begin{array}{l}\text { Bradycardia, } \\
\text { weakness }\end{array}$ & 35 & 8.6 & $\begin{array}{l}\text { Dopamine, isoproterenol, } \\
\text { calcium, insulin, dextrose, } \\
\text { polysterene sulfonate }\end{array}$ \\
\hline 2019 & Gonuguntla $^{7}$ & 67 & Diltiazem, nadolol & $\begin{array}{l}\text { Dizziness, weakness, } \\
\text { diarrhea }\end{array}$ & $20 \mathrm{~s}$ & - & Fluids, dopamine infusion \\
\hline 2019 & Diribe et $a l .^{8}$ & 52 & $\begin{array}{l}\text { Carvedilol, } \\
\text { epleronone, TMP/ } \\
\text { SMX }\end{array}$ & Syncope & 20 & 8.6 & $\begin{array}{l}\text { Calcium, insulin, dextrose, } \\
\text { albuterol, diuresis, } \\
\text { potassium binder }\end{array}$ \\
\hline 2020 & Liou $^{9}$ & 55 & $\begin{array}{l}\text { Diltiazem, } \\
\text { metoprolol }\end{array}$ & $\begin{array}{l}\text { Heart failure, atrial } \\
\text { flutter }\end{array}$ & - & - & $\begin{array}{l}\text { Glucagon, calcium, insulin, } \\
\text { dextrose }\end{array}$ \\
\hline 2020 & Cheung $^{10}$ & 77 & Metoprolol, lisinopril & Vomiting & 38 & 6.4 & $\begin{array}{l}\text { Atropine, dopamine } \\
\text { infusion, calcium }\end{array}$ \\
\hline 2020 & Srivastava $^{11}$ & 62 & Carvedilol & Weakness & $30 \mathrm{~s}$ & 8.0 & $\begin{array}{l}\text { Potassium binders, fluids, } \\
\text { dopamine infusion }\end{array}$ \\
\hline 2020 & Golchin $^{12}$ & 84 & Beta blocker & Weakness, polyuria & $30 \mathrm{~s}$ & 7.1 & Dialysis, dopamine infusion \\
\hline 2020 & Prabhu $^{13}$ & 75 & Carvedilol, verapamil & $\begin{array}{l}\text { Syncope, } \\
\text { hypotension, } \\
\text { bradycardia }\end{array}$ & 33 & 6.5 & $\begin{array}{l}\text { Dopamine infusion, calcium, } \\
\text { insulin, bicarbonate, fluids }\end{array}$ \\
\hline 2020 & Arif $^{14}$ & 55 & Diltiazem & $\begin{array}{l}\text { Dyspnea, edema, } \\
\text { drowsiness }\end{array}$ & $30 \mathrm{~s}$ & 5.4 & Dopamine infusion, dialysis \\
\hline 2020 & Grigorov $^{15}$ & 43 & $\begin{array}{l}\text { Diltiazem, } \\
\text { metoprolol }\end{array}$ & $\begin{array}{l}\text { Lethargy, went into } \\
\text { PEA }\end{array}$ & 35 & 7.6 & $\begin{array}{l}\text { Fluids, norepinephrine } \\
\text { infusion, insulin, dextrose, } \\
\text { bicarbonate, calcium, } \\
\text { transfer for higher level of } \\
\text { care }\end{array}$ \\
\hline 2020 & Barreras $^{16}$ & 80 & Beta-blocker & Found down & 33 & 5.3 & ACLS for PEA, expired \\
\hline 2020 & Sattar $^{17}$ & 66 & Carvedilol, & Pre-syncope & 35 & 6.2 & Fluids, calcium, insulin \\
\hline 2020 & Sarvottam $^{18}$ & 63 & Beta-blocker & $\begin{array}{l}\text { Generalized } \\
\text { weakness }\end{array}$ & 40 & 9.0 & $\begin{array}{l}\text { Calcium, insulin, dextrose, } \\
\text { albuterol, dialysis }\end{array}$ \\
\hline 2020 & Flores $^{19}$ & 74 & Metoprolol, lisinopril & Anaphylaxis & 40 & 7.1 & $\begin{array}{l}\text { Epinephrine infusion, } \\
\text { calcium, albuterol }\end{array}$ \\
\hline 2020 & Savage $^{20}$ & 81 & Atenolol, ramipril & Stroke & 29 & 8.3 & Dialysis, atropine \\
\hline
\end{tabular}


Table 1. BRASH Case Series and Reports (Continued)

\begin{tabular}{|c|c|c|c|c|c|c|c|}
\hline Year & Author & Age & Medications & Chief Complaint & HR & $\mathbf{K}+$ & Treatment \\
\hline 2020 & Nathani $^{21}$ & 62 & $\begin{array}{l}\text { Metoprolol, } \\
\text { nifedipine }\end{array}$ & Diarrhea, weakness & 38 & 6.4 & $\begin{array}{l}\text { Fluid, calcium, insulin, } \\
\text { dextrose, albuterol, } \\
\text { bicarbonate infusion, } \\
\text { atropine }\end{array}$ \\
\hline 2021 & Vishnu $^{22}$ & 60 & Atenolol, amlodipine & $\begin{array}{l}\text { Abdominal pain, } \\
\text { nausea and vomiting, } \\
\text { syncope, dizziness }\end{array}$ & 32 & 6.2 & $\begin{array}{l}\text { Calcium, insulin, dextrose, } \\
\text { albuterol, bicarbonate push, } \\
\text { isoproterenol, dialysis }\end{array}$ \\
\hline \multirow[t]{2}{*}{2021} & \multirow[t]{2}{*}{$\begin{array}{l}\text { Wong }{ }^{23} \\
\text { (case series) }\end{array}$} & 62 & Atenolol, diltiazem & Vomiting, diarrhea & 40 & 6.2 & $\begin{array}{l}\text { Dopamine infusion, } \\
\text { insulin, dextrose, calcium, } \\
\text { epinephrine }\end{array}$ \\
\hline & & 44 & $\begin{array}{l}\text { Diltiazem, } \\
\text { metoprolol }\end{array}$ & Dizziness & 48 & 5.5 & $\begin{array}{l}\text { Dopamine infusion, calcium, } \\
\text { insulin, dextrose }\end{array}$ \\
\hline 2021 & $\mathrm{Ata}^{24}$ & 64 & $\begin{array}{l}\text { Bisprolol, sacubitril/ } \\
\text { val-sartan }\end{array}$ & $\begin{array}{l}\text { Fatigue, diarrhea, } \\
\text { vomiting, anorexia }\end{array}$ & 28 & 5.8 & $\begin{array}{l}\text { Fluids, insulin, dextrose, } \\
\text { salbutamol, dialysis; expired }\end{array}$ \\
\hline 2021 & Ahad $^{25}$ & 63 & Metoprolol, losartan & $\begin{array}{l}\text { Malaise, dyspnea, } \\
\text { vomiting, diarrhea }\end{array}$ & 21 & 5.9 & $\begin{array}{l}\text { Atropine, glucagon; fluids, } \\
\text { epinephrine infusion, } \\
\text { calcium, dextrose, insulin }\end{array}$ \\
\hline 2021 & Gulati $^{26}$ & 58 & $\begin{array}{l}\text { Enalapril, } \\
\text { amiodarone }\end{array}$ & Chills, dyspnea & $40 \mathrm{~s}$ & 5.2 & $\begin{array}{l}\text { Fluids, albumin, calcium, } \\
\text { bumetanide }\end{array}$ \\
\hline
\end{tabular}

HR: heart rate; $\mathrm{K}+$ : serum potassium level, in $\mathrm{mmol} / \mathrm{L}$.

treated with chronotropic agents, preferably epinephrine, which also can cause intracellular potassium shift. ${ }^{3}$ Hypotension should be treated with fluid resuscitation, typically with a balanced crystalloid or isotonic bicarbonate in the setting of acidosis. Caution should be exercised if the patient has underlying congestive heart failure or anuric renal failure, which could precipitate pulmonary edema. ${ }^{2,3}$

A review of literature for "BRASH syndrome" was conducted via PubMed and Google Scholar and revealed 23 publications, including case series and case reports published from 2019 to the present time with a total of 66 patients described (Table 1). The average patient age was 68.1 years old, presented most often with weakness and dizziness, had an average heart rate around 35 beats per minute, and mean serum potassium of $6.6 \mathrm{mmol} / \mathrm{L}$. Of the 66 patients, 65 were on a beta-blocker or calcium channel blocker. One patient's ${ }^{26}$ source of AV nodal blockade was due to amiodarone. Two of the 66 patients died. ${ }^{16,24}$ In most of the cases reported, a known cause of hypotension was present. Diarrhea and vomiting were most common, and there was one case of anaphylaxis related hypovolemia. ${ }^{19}$ However, in two cases, antibiotics and nephrotic syndrome were implicated in the development of BRASH syndrome..$^{8,26}$

\section{KEY POINTS}

- Consider BRASH syndrome in an elderly patient with cardiac disease treated with an $\mathrm{AV}$ nodal blocker, baseline renal dysfunction, and a cause for hypoperfusion.

- If suspected, address metabolic derangements, hypotension, and bradycardia concurrently.

- Use urine output to direct medical therapy for renal failure and hyperkalemia.

- Anticipate reversal of symptoms relatively quickly once identified and treated appropriately. 
Article citation: Vangipuram D, Nugent K. BRASH syndrome: More than just syncope. The Southwest Respiratory and Critical Care Chronicles 2021;9(40): 53-59

From: Department of Internal Medicine, Texas Tech University Health Sciences Center, Lubbock, Texas

Submitted: $4 / 25 / 2021$

Accepted: 6/25/2021

Reviewer: Deephak Swaminath MD

Conflicts of interest: none

This work is licensed under a Creative Commons

Attribution-ShareAlike 4.0 International License.

\section{REFERENCES}

1. Hegazi MO, Aldabie G, Al-Murtairi S, et al. Junctional bradycardia with verapamil in renal failure-care required even with mild hyperkalemia. J Clin Pharm and Therap 2012; 37(6):726-728.

2. Farkas J, Long B, Koyfman A, et al. BRASH syndrome: bradycardia, renal failure, AV blockade, shock, and hyperkalemia. J Emer Med 2020;59(2):216-223.

3. Farkas J. PulmCrit- BRASH syndrome: Bradycardia, renal failure, AV blocker, shock, hyperkalemia. EMCrit Project. 2017. Available at: https://emcrit.org/pulmcrit/brashsyndrome-bradycardia-renal-failure-av-blocker-shockhyperkalemia/

4. Schnaubelt S, Roeggla M, Spiel AO, et al. BRASH syndrome: an interaction of bradycardia, renal failure, AV block, shock and hyperkalemia. Internal and Emergency Medicine 2021;16:509-511.

5. Ravioli S, Woitok BK, Lindner G. BRASH syndrome-fact or fiction? A first analysis of the prevalence and relevance of a newly described syndrome. Eur J Emerg Med 2021;28(2): 153-155.

6. Sohal S, Ramachandran A. Syndrome of bradycardia, renal failure, atrioventricular nodal blockers, shock, and hyperkalemia (BRASH syndrome): a new clinical entity? CHEST 2019;156(4):A74.

7. Gonuguntla K, Patil S, Manek G, et al. Brash syndrome: lost in plain sight. CHEST Case Reports 2019;156(4): a2228.

8. Diribe N, Le J. TMP/SMX-induced bradycardia, renal failure, AV node blockers, shock, and hyperkalemia syndrome. Clin Pract Cases Emerg Med 2019;3(3):282-285.
9. Liou J, Kaneria A, Weiss S. Brash syndrome: an entity between hyperkalemia and atrioventricular nodal blockade toxicity. CHEST Critical Care 2020;158(4):a937.

10. Cheung JC, Law KL, Lam KN. Too slow and too high. Hong Kong Journal of Emergency Medicine. 2020. Available at: https://journals.sagepub.com/doi/full/10.1177/ 1024907920931721

11. Srivastava $S$, Kemnic T, Hildebrandt KR. BRASH syndrome. BMJ Case Reports 2020;13(2):1-3.

12. Golchin A, Zhou M, Khan AH. Bradycardia, renal failure, AV-nodal blockers, shock, and hyperkalemia (BRASH)-a new clinical syndrome. American Thoracic Society International Conference Abstracts 2020;201:A3467.

13. Prabhu V, Hsu E, Lestin A, et al. Bradycardia, renal failure, atrioventricular nodal blockade, shock, and hyperkalemia (BRASH) syndrome as a presentation of coronavirus disease 2019. Cureus 2020;12(4):e7816.

14. Arif AW, Khan MS, Masri A, et al. BRASH syndrome with hyperkalemia: an under-recognized clinical condition. Methodist Debakey Cardiovascular J 2020;16(3):241244.

15. Grigorov MV, Belur AD, Otero D, et al. The BRASH syndrome, a synergistic arrhythmia phenomenon. Baylor Univ Medical Center Proceedings 2020;33(4):668670 .

16. Barreras N. Brash syndrome, can you see the cycle? Am J Respir Crit Care Med 2020;201:a5184.

17. Sattar Y, Bareega SB, Rauf H, et al. Bradycardia, renal failure, atrioventricular nodal blocker, shock, and hyperkalemia syndrome diagnosis and literature review. Cureus 2020; 12(2):e6985.

18. Sarvottam K, McDonald N, Patarroyo G. Brash syndromeshould there be a lower threshold to dialyze? Am J Respir Crit Care Med 2020;201:a5183.

19. Flores S. Anaphylaxis induced bradycardia, renal failure, AV nodal blockade, shock, and hyperkalemia: A-BRASH in the emergency department. Am J Emerg Med 2020;38(9): 1987.e1-1987.e3.

20. Savage P, McEneaney D. Brash syndrome: an under recognized cause of complete heart block in the elderly. Ulster Med J 2020;89(2):123-124.

21. Nathani A, Lingamaneni P, Radigan KA. Brash syndrome: an emerging clinical entity. AM J Respir Crit Care Med 2020;201:A1666.

22. Vishnu VK, Jamshed N, Amrithanand VT, et al. BRASH syndrome: a case report. Journal of Emergency Medicine 2021: in print.

23. Wong CK, Jaafar MJ. Bradycardia, renal failure, atrioventricular nodal bloackade, shock, and hyperkalemia: 
an important syndrome to recognize. Turk J Emerg Med. Available at: https://www.turkjemergmed.org/preprintarticle.asp?id=309138

24. Ata F, Yasir M, Javed S, et al. Diagnostic and therapeutic challenges of BRASH syndrome: a case report. Medicine Case Reports and Study Protocols 2021;2:e0018.
25. Ahad A. BRASH syndrome with complete heart block: a unique presentation of a novel clinical syndrome. Critical Care Medicine 2021;49(1):647.

26. Gulati U, Nanduri A, Juneja $P$, et al. An atypical case of COVID-19 and renal amyloidosis presenting with BRASH syndrome. Critical Care Medicine 2021;49(1):146. 